\title{
Poor post-silking kernel development limits summer maize yield in the North China Plain
}

\author{
Hongbin Tao ${ }^{\mathrm{a}}$, Laikun Xia ${ }^{\mathrm{a}, \mathrm{b}}$, Lina Xu $\mathrm{Xu}^{\mathrm{a}, \mathrm{c}}$, Lihua $\mathrm{Lu}^{\mathrm{a}, \mathrm{d}}$, Pengyu Jin ${ }^{\mathrm{a}}$, Bo Ming ${ }^{\mathrm{a}}$, Caicai Wang ${ }^{\mathrm{a}, \mathrm{e}}$, \\ Pu Wang, \\ ${ }^{a}$ Department of Agronomy, China Agricultural University, Beijing 100193, China \\ b The Cereal Crops Institute, Henan Academy of Agricultural Sciences, Zhengzhou 450002, China \\ c School of Science and Technology, Henan Institute of Science and Technology, Xinxiang 453003, China \\ ${ }^{d}$ Institute of Cereal and Oil Crops, Hebei Academy of Agricultural and Forestry Sciences, \\ Shijiazhuang 050035, China \\ e Shanghai Organic and Beyond Corp., Shanghai 200120, China
}

*Corresponding author, e-mail: wangpu@cau.edu.cn

Received 14 Sep 2014

Accepted 31 Aug 2015

\begin{abstract}
Winter wheat (Triticum aestivum)/summer maize (Zea mays) rotation is a major system in the North China Plain. The wheat yield target was achieved recently, whereas the maize yield has been static since the 2000s, even with high density planting and fertilizer input. This study analyses the factors limiting maize growth and yield. Maize yields from eight field trials (2006-2011) were classified into five levels: low yield $(<8.25)$, farmer yield (8.25-9.75), experimental yield (9.75-11.25), record high yield (11.25-12.75), and target yield ( $>12.75)$ t/ha. Shoot dry weight, nitrogen accumulation, and leaf area index at critical stages, yield, and yield components were measured. Grain yield fluctuated from 6.4-13.8 t/ha (10.1 t/ha on average). Insufficient kernel number per ear and low kernel weight limited further yield improvement. Shoot dry weight, leaf area index, and shoot N-accumulation before silking did not vary among the different yield levels, whereas after silking these parameters were significant larger at high yield levels. It can be concluded that low kernel number per ear across yield levels was related to source limitation pre-silking. Additionally, low kernel weight was due to poor post-silking dry matter production. However, the potential of yield increment through increasing source size was limited under the current system. Strategies to enhance post-silking leaf and root function shall therefore be considered to improve post-silking dry matter production and transportation under a high density and high nitrogen input system.
\end{abstract}

KEYWORDS: leaf area index, dry matter, nitrogen, root growth

\section{INTRODUCTION}

Winter wheat (Triticum aestivum) and summer maize (Zea mays) are two major crops within a rotation system in North China Plain (NCP), and account for about $60 \%$ of arable land (Chinese Statistics Year Book, 2012). There are seven provinces (cities) involved in this area ${ }^{1}$ where summer maize is traditionally sowed one week before or directly after the harvesting of winter wheat depending on meteorological conditions at different locations within NCP. Annual regional grain yield (winter wheat plus summer maize) ranges from $11-13 \mathrm{t} / \mathrm{ha}^{2,3}$ with a tendency of a tremendous yield increase since the 1960s but relatively stable yield after mid-1990s in $\mathrm{NCP}^{4}$.

According to the results of modelling, potential yield of winter wheat can reach $9.75 \mathrm{t} / \mathrm{ha}^{5}$, and
13-15 $t$ /ha for summer maize ${ }^{6}$. In recent years, the experimental grain yield of winter wheat is stabilized at 9-9.5 $\mathrm{t} / \mathrm{ha}^{7}$, and that of summer maize is around 9-11.5 $\mathrm{t} / \mathrm{ha}^{8,9}$. Since winter wheat usually consumes large amount of water, the environmental cost for yield improving would become higher and higher under current yield level. Thus more attention is paid on the improvement of summer maize yield due to its high yield potential.

In the NCP, plant density increased to as high as 9-12 plants per $\mathrm{m}^{2}$ and was applied for several varieties under experimental condition, while the increment of maize yield reached plateau at $10-11 \mathrm{t} / \mathrm{ha}^{10}$, implying little contribution to yield improvement through the increase of density with current varieties. Additionally, plant growth regulator was also applied to summer maize in order to increase the density resistance without obtaining 
Table 1 Metrological condition of maize growing season in Heilonggang River Valley from 1996-2011.

\begin{tabular}{|c|c|c|c|c|c|c|c|c|c|}
\hline & \multicolumn{2}{|c|}{ June } & \multicolumn{2}{|c|}{ July } & \multicolumn{2}{|c|}{ August } & \multicolumn{2}{|c|}{ September } & \multirow{2}{*}{$\begin{array}{c}\text { October } \\
01-15\end{array}$} \\
\hline & $01-15$ & $16-30$ & $01-15$ & $16-31$ & $01-15$ & $16-31$ & $01-15$ & $16-30$ & \\
\hline Average daily temperature $\left({ }^{\circ} \mathrm{C}\right)$ & 25.1 & 26.6 & 27.5 & 27.5 & 27.0 & 24.7 & 22.7 & 20.0 & 16.4 \\
\hline Average daily temperature range $\left({ }^{\circ} \mathrm{C}\right)$ & 12.1 & 10.8 & 9.8 & 8.4 & 8.4 & 8.9 & 10.1 & 10.7 & 10.7 \\
\hline Cumulative precipitation (mm) & 19.3 & 56.2 & 69.6 & 86.5 & 67.3 & 52.4 & 24.0 & 18.1 & 29.4 \\
\hline Average daily relative humidity (\%) & 54.6 & 64.1 & 69.5 & 76.6 & 77.7 & 77.2 & 72.4 & 68.4 & 66.4 \\
\hline Average daily sunshine hours (h) & 8.9 & 7.6 & 7.5 & 6.5 & 6.8 & 7.1 & 7.4 & 7.1 & 6.7 \\
\hline
\end{tabular}

Table 2 Soil chemical properties of the experimental field from 2006-2011.

\begin{tabular}{lcccccc}
\hline $\begin{array}{l}\text { Soil depth } \\
(\mathrm{cm})\end{array}$ & $\begin{array}{c}\text { Organic matter } \\
(\mathrm{g} / \mathrm{kg})\end{array}$ & $\begin{array}{c}\text { Total } \mathrm{N} \\
(\mathrm{g} / \mathrm{kg})\end{array}$ & $\begin{array}{c}\text { Available N } \\
(\mathrm{mg} / \mathrm{kg})\end{array}$ & $\begin{array}{c}\text { Olsen-P } \\
(\mathrm{mg} / \mathrm{kg})\end{array}$ & $\begin{array}{c}\text { Exchangeable K } \\
(\mathrm{mg} / \mathrm{kg})\end{array}$ & $\begin{array}{c}\text { Bulk density } \\
\left(\mathrm{g} / \mathrm{cm}^{3}\right)\end{array}$ \\
\hline $0-20$ & $10.4 \pm 1.7^{\dagger}$ & $0.9 \pm 0.2$ & $67 \pm 14$ & $24 \pm 14$ & $131 \pm 29$ & 1.51 \\
$20-40$ & $5.3 \pm 1.1$ & $0.4 \pm 0.1$ & $34.2 \pm 7.8$ & $3.4 \pm 1.2$ & $94 \pm 19$ & 1.48 \\
\hline
\end{tabular}

$\dagger$ Standard deviation.

a significant yield improvement ${ }^{11}$. Furthermore, many experiments on nitrogen fertilization regimes, i.e., fertilizer type, timing, and doses, were conducted $^{9,12}$. A suitable $\mathrm{N}$ application rate was determined and $\mathrm{N}$ supply at three-leaf and twelveleaf stages was essential to achieve high efficiency and yield ${ }^{8,13}$. These efforts however were unable to achieve a stable yield higher than $11.5 \mathrm{t} / \mathrm{ha}$ until now. It is urgently needed to understand the summer maize growing system and to break the bottlenecks of yield improvements in NCP.

We designed eight field trials in order to: (1) understand maize growing and nitrogen accumulation character under different yield levels, (2) analyse the constraints to yield improvement, and (3) suggest the possible solutions to break the bottlenecks on yield improvement.

\section{MATERIALS AND METHODS}

\section{Site description and data sources}

Field experiments were conducted from 2006-2011 at Wuqiao Experimental Station of China Agricultural University $\left(37^{\circ} 41^{\prime} \mathrm{N}, 116^{\circ} 37^{\prime} \mathrm{E}, 18 \mathrm{~m}\right.$ asl), Hebei Province, China. This area has a typical semihumid continental monsoon climate. Meteorological data of maize growing season (1996-2011) were obtained from China Meteorological Data Sharing Service System (www.cdc.cma.gov.cn) and shown in Table 1. Samples from nine points were taken with a shape of ' $S$ ' across the field at the on-set of each experiment. The soil texture of the experimental site was light loam with $\mathrm{pH}$ value greater than 8 . The chemical properties at $0-20 \mathrm{~cm}$ and $20-40 \mathrm{~cm}$ soil depth were measured and are presented in Table 2.
Data used in this paper were based on eight field experiments conducted on station from 20062011. ZD958, a commercially available and widely used cultivar, was applied under different plant densities and nitrogen fertilization rates in all experimental years (Table 3). Within each field experiment, a complete randomized block design was applied with three or four replicates. In relation to different plant densities and nitrogen fertilization rates, yields were classified into five levels for growth analysis: (1) low yield, grain yields (14\% water content) less than regional average yield ( $<8.25 \mathrm{t} / \mathrm{ha}, n=14$ ); (2) farmer yield, regional average yield (8.25-9.75 t/ha, $n=38$ ); (3) experimental yield $^{12,13}$, average yield of scientific experiments in this region (9.75-11.25 t/ha, $n=54$ ); (4) record high yield ${ }^{14}$, the highest yield in this region (11.25-12.75 t/ha, $n=21$ ); and (5) target yield ${ }^{10}$, modelled grain yields $(>12.75 \mathrm{t} / \mathrm{ha}$, $n=3$ ).

\section{Field managements}

Summer maize was directly seeded after the harvest of winter wheat without tillage. Maize seeds were sowed on 14-20 June and harvested from 27 September to 10 October according to the maturity. Irrigation was conducted only once before sowing or no irrigation during the entire growing period according to soil moisture at sowing. $\mathrm{P}$ and $\mathrm{K}$ fertilizers were applied as the basal fertilizers, while $\mathrm{N}$ fertilizer was applied as the basal and top-dressing fertilizer. Detailed field managements are presented in Table 3. Propisochlor (2-chloro-6'-ethyl$\mathrm{N}$-isopropoxymethylacet-o-toluidide) and atrazine 
Table 3 Field managements of nine experiments conducted in Wuqiao experimental station of China Agricultural University from 2006-2011.

\begin{tabular}{|c|c|c|c|c|c|c|c|c|c|}
\hline Year & $\begin{array}{l}\text { Experiment } \\
\text { code }\end{array}$ & $\begin{array}{l}\text { Plant density } \\
\text { (plants } / \mathrm{m}^{2} \text { ) }\end{array}$ & $\begin{array}{l}\text { Plot size } \\
\left(\mathrm{m}^{2}\right)\end{array}$ & $\begin{array}{l}\text { Sowing } \\
\text { date }\end{array}$ & $\begin{array}{c}\text { Harvest } \\
\text { date }\end{array}$ & $\begin{array}{l}\text { Irrigation } \\
(\mathrm{mm})\end{array}$ & $\begin{array}{c}\mathrm{N} \\
(\mathrm{kg} / \mathrm{ha})\end{array}$ & $\begin{array}{c}\mathrm{P}_{2} \mathrm{O}_{5} \\
\text { (kg/ha) }\end{array}$ & $\begin{array}{c}\mathrm{K}_{2} \mathrm{O} \\
(\mathrm{kg} / \mathrm{ha})\end{array}$ \\
\hline $\begin{array}{l}2006 \\
2007\end{array}$ & $\begin{array}{l}1 \\
2\end{array}$ & $\begin{array}{c}8.25,9.75,11.25 \\
8.25\end{array}$ & $\begin{array}{l}42 \\
42\end{array}$ & $\begin{array}{l}17 \text { June } \\
16 \text { June }\end{array}$ & $\begin{array}{c}3 \text { October } \\
27 \text { September }\end{array}$ & $\begin{array}{l}60 \\
60\end{array}$ & $\begin{array}{l}0,90,180,270^{\dagger} \\
0,90,180,270^{\dagger}\end{array}$ & $\begin{array}{l}103.5 \\
103.5\end{array}$ & $\begin{array}{l}112.5 \\
112.5\end{array}$ \\
\hline $\begin{array}{l}2007 \\
2007\end{array}$ & $\begin{array}{l}3 \\
4\end{array}$ & $\begin{array}{l}8.25 \\
8.25\end{array}$ & $\begin{array}{l}50.4 \\
50.4\end{array}$ & $\begin{array}{l}17 \text { June } \\
17 \text { June }\end{array}$ & $\begin{array}{l}5 \text { October } \\
5 \text { October }\end{array}$ & $\begin{array}{l}75 \\
75\end{array}$ & $\begin{array}{l}75,120,300^{\dagger} \\
75,120,300^{\ddagger}\end{array}$ & $\begin{array}{l}105 \\
105\end{array}$ & $\begin{array}{l}120 \\
120\end{array}$ \\
\hline $\begin{array}{l}2008 \\
2009\end{array}$ & $\begin{array}{l}5 \\
6\end{array}$ & $\begin{array}{l}8.25 \\
8.25\end{array}$ & $\begin{array}{l}54 \\
54\end{array}$ & $\begin{array}{l}11 \text { June } \\
14 \text { June }\end{array}$ & $\begin{array}{l}2 \text { October } \\
2 \text { October }\end{array}$ & $\begin{array}{l}150 \\
150\end{array}$ & $\begin{array}{l}0,120,150 \\
\quad 180,240^{\S}\end{array}$ & $\begin{array}{l}90 \\
90\end{array}$ & $\begin{array}{l}90 \\
90\end{array}$ \\
\hline $\begin{array}{l}2010 \\
2011\end{array}$ & $\begin{array}{l}7 \\
8\end{array}$ & $\begin{array}{l}6,7.5,9 \\
6,7.5,9\end{array}$ & $\begin{array}{l}57.6 \\
43.2\end{array}$ & $\begin{array}{l}20 \text { June } \\
15 \text { June }\end{array}$ & $\begin{array}{l}17 \text { October } \\
10 \text { October }\end{array}$ & $\begin{array}{l}0 \\
0\end{array}$ & $\begin{array}{l}0,180,270 \\
0,180,270^{ף}\end{array}$ & $\begin{array}{l}105 \\
105\end{array}$ & $\begin{array}{l}120 \\
120\end{array}$ \\
\hline
\end{tabular}

${ }^{\dagger} \mathrm{N}$ applied with a ratio of $1: 4$ as basal and top-dressing at 12 collars stage.

$\$ \mathrm{~N}$ applied with a ratio of $1: 2$ at 3 collars and 12 collars stage, respectively.

$\S \mathrm{N}$ applied at $0,30,60$, and $120 \mathrm{~kg} / \mathrm{ha}$ at 3 collars stage, and $120 \mathrm{~kg} / \mathrm{ha}$ at 12 collars stage for all treatments.

` $\mathrm{N}$ applied at 30 and $120 \mathrm{~kg} / \mathrm{ha}$ at 3 collars stage for both $\mathrm{N}$ treatments, and 120 and $30 \mathrm{~kg} / \mathrm{ha}$ at 12 collars stage respective silking stage for all. $\mathrm{N}$ applied with a ratio of $1: 1$ as basal and top-dressing at 12 collars stage.

(6-chloro- $\mathrm{N}^{2}$-ethyl- $\mathrm{N}^{4}$-isopropyl-1,3,5-triazine-2,4diamine) were applied directly after sowing to suppress the emergence of weed. Cyhalothrin $\{(\mathrm{RS})-\alpha-$ cyano-3-phenoxybenzyl-(1RS,3RS)-3[(Z)-2-chloro3,3,3-trifluoropropenyl]-2,2-dimethylcyclopanecarboxylate\} were applied to control pests when necessary.

\section{Plant sampling and measurements}

Maize developmental stages were classified as six collars (V6), nine collars (V9), twelve collars (V12), silking (R1), blister (R2), and physiological maturity stage (R6). At V6, V9, V12, R1 and R6 stages, plant samples were collected from the sampling area. A fixed and non-disturbed area (final harvest area) within each plot was determined when experiments were settled up, which were only used for measuring grain yield and yield components. On each sampling campaign, three or four plants were harvested around the final harvest area of each plot. Plants aboveground parts were separated into green leaves, stems (including leaf sheaths and necrotic leaves), and ears (when present). Leaf area was determined by measuring length and width of leaves. Leaf area index (LAI) was calculated as leaf area per unit of land area $(L A=$ length $\times$ width $\times 0.75$ ). Shoot dry matter was determined after oven-drying at $80^{\circ} \mathrm{C}$ to a constant weight. Dry plant samples were ground and digested by $\mathrm{H}_{2} \mathrm{SO}_{4}-\mathrm{H}_{2} \mathrm{O}_{2}$, and the $\mathrm{N}$ concentration was measured by Kjeldahl method. At physiological maturity, the final harvest area $\left(9.6 \mathrm{~m}^{2}\right)$ was harvested by hands to determine the maize yields ( $14 \%$ water content). Ten ears were randomized picked within the final harvest area to measure kernel number per ear and 1000-kernel weight.

\section{Data calculation and statistical analysis}

Each plot of experiment 1 to experiment 8 represented one data point, and thus 130 data points totally. These 130 data points were classified to five levels according to their final yield, and thus growth parameters and their relationships with yield were analysed among yield levels. ANOVA was performed with general linear model procedure of the Statistical Analysis System, version 9.0 (SAS Institute Inc., 2002). Correlations between parameters were checked according to Pearson correlation in SAS.

\section{RESULTS}

Generally, the grain yield on station ranged from 6.4-13.8 t/ha with an average yield of $10.1 \mathrm{t} / \mathrm{ha}$, and ear numbers ranged from $14.5-30.3 \times 10^{3}$ per ha, kernel number per ear ranged from $273-574$, and 1000-kernel weight ranged from 227-356 g over six experimental years. The coefficients of variation for these averages were $10.8-17 \%$ (Table 4). With the increase of yield levels, ear number per ha was similar at around 80000 , while kernel number per ear increased, and significant difference occurred between high yield levels ( $>11.25 \mathrm{t} / \mathrm{ha}$ ) and low yield levels $(<11.25 \mathrm{t} / \mathrm{ha})$. On the contrary, 1000-kernel weight at low yields was greater than at high yield.

Grain dry weight increased sequentially with the increase of yield levels, while straw dry weight at harvest showed no difference among yield levels (Table 5). Moreover, grain $\mathrm{N}$ accumulation significantly increased with the increase of yield level, while straw $\mathrm{N}$ accumulation only increased slightly with no statistic difference among yield levels. Moreover, the higher the grain yield, the 
Table 4 Number of observations (no. obs.; amount of data points), yield levels, and coefficient of variation (CV) of grain yield (14\% water content) and yield components of summer maize in Wuqiao experimental station of China Agricultural University from 2006-2011.

\begin{tabular}{lccccc}
\hline $\begin{array}{l}\text { No. } \\
\text { obs. } \\
(n)\end{array}$ & $\begin{array}{c}\text { Grain } \\
\text { yield level } \\
(\mathrm{t} / \mathrm{ha})\end{array}$ & $\begin{array}{c}\text { Average } \\
\text { grain yield } \\
(\mathrm{t} / \mathrm{ha})\end{array}$ & $\begin{array}{c}\text { Ear } \\
\text { number } \\
\left(\times 10^{3} / \mathrm{ha}\right)\end{array}$ & $\begin{array}{c}\text { Kernel } \\
\text { number } \\
(\text { No./ear })\end{array}$ & $\begin{array}{c}1000-\text {-kernel } \\
\text { weight } \\
(\mathrm{g})\end{array}$ \\
\hline 14 & $<8.25$ & $7.5^{\mathrm{e}}$ & $81.8^{\mathrm{a}}$ & $389^{\mathrm{b}}$ & $292^{\mathrm{a}}$ \\
38 & $8.25-9.75$ & $9.2^{\mathrm{d}}$ & $78.4^{\mathrm{a}}$ & $398^{\mathrm{b}}$ & $282^{\mathrm{ab}}$ \\
54 & $9.75-11.25$ & $10.5^{\mathrm{c}}$ & $79.4^{\mathrm{a}}$ & $385^{\mathrm{b}}$ & $285^{\mathrm{ab}}$ \\
21 & $11.25-12.75$ & $11.9^{\mathrm{b}}$ & $83.9^{\mathrm{a}}$ & $494^{\mathrm{a}}$ & $258^{\mathrm{b}}$ \\
3 & $>12.75$ & $13.6^{\mathrm{a}}$ & $78.8^{\mathrm{a}}$ & $423^{\mathrm{a}}$ & $256^{\mathrm{b}}$ \\
130 & $6.4-13.8$ & 10.1 & $145.4-30.3$ & $273-574$ & $227-356$ \\
$\mathrm{CV}(\%)$ & 14.1 & - & 17.0 & 15.5 & 10.8 \\
\hline
\end{tabular}

Figures within each column followed by the same letters are not significantly different, $p<0.05$.

Table 5 Grain dry weight (GDrW), straw dry weight (SDrW), grain $\mathrm{N}$ accumulation (GN), straw $\mathrm{N}$ accumulation (SN), harvest index (HI), and nitrogen harvest index (NHI) of summer maize in Wuqiao experimental station of China Agricultural University from 2006-2011.

\begin{tabular}{lcccccc}
\hline $\begin{array}{l}\text { Yield level } \\
\text { (t/ha) }\end{array}$ & $\begin{array}{c}\text { GDrW } \\
\text { (t/ha) }\end{array}$ & $\begin{array}{c}\text { SDrW } \\
(\mathrm{t} / \mathrm{ha})\end{array}$ & $\begin{array}{c}\text { GN } \\
(\mathrm{kg} / \mathrm{ha})\end{array}$ & $\begin{array}{c}\text { SN } \\
(\mathrm{kg} / \mathrm{ha})\end{array}$ & HI & NHI \\
\hline$<8.25$ & $6.5^{\mathrm{e}}$ & $9.5^{\mathrm{a}}$ & $93.1^{\mathrm{d}}$ & $61.5^{\mathrm{a}}$ & $0.41^{\mathrm{d}}$ & $0.60^{\mathrm{a}}$ \\
$8.25-9.75$ & $7.9^{\mathrm{d}}$ & $9.3^{\mathrm{a}}$ & $112.0^{\mathrm{cd}}$ & $63.5^{\mathrm{a}}$ & $0.46^{\mathrm{c}}$ & $0.64^{\mathrm{a}}$ \\
$9.75-11.25$ & $9.1^{\mathrm{c}}$ & $9.7^{\mathrm{a}}$ & $125.7^{\mathrm{bc}}$ & $74.0^{\mathrm{a}}$ & $0.48^{\mathrm{bc}}$ & $0.63^{\mathrm{a}}$ \\
$11.25-12.75$ & $10.3^{\mathrm{b}}$ & $9.3^{\mathrm{a}}$ & $138.2^{\mathrm{b}}$ & $80.9^{\mathrm{a}}$ & $0.53^{\mathrm{ab}}$ & $0.63^{\mathrm{a}}$ \\
$>12.75$ & $11.7^{\mathrm{a}}$ & $10.2^{\mathrm{a}}$ & $170.2^{\mathrm{a}}$ & $77.7^{\mathrm{a}}$ & $0.54^{\mathrm{a}}$ & $0.69^{\mathrm{a}}$ \\
\hline
\end{tabular}

Figures within each column followed by the same letters are not significantly different, $p=0.05$.

greater the harvest index, but nitrogen harvest index values were similar under different yield levels.

Shoot dry weight, leaf area index, and shoot $\mathrm{N}$ accumulation showed no statistical difference among yield levels at 6 collars stage (V6, data not shown), 9 collars stage (V9), and silking stage (R1) (Fig. 1). However, significant difference was observed at physiological maturity (R6), i.e., with the increase of yield levels, shoot dry matter, leaf area index, and shoot $\mathrm{N}$ accumulation all increased significantly during silking to physiological maturity (Fig. 1).

Increase of straw dry weight had no impact on grain dry weight, while shoot dry weight significantly related to grain dry weight (Fig. 2a and Fig. 2b). Grain dry weight achieved the highest value of $11.8 \mathrm{t} /$ ha when shoot dry weight reached $29.2 \mathrm{t} / \mathrm{ha}$ according to the correlation equation. Moreover, leaf area index at silking did not affect the yield levels, while a significant correlation was found between leaf area index at harvest and grain dry weight, suggesting delaying of leaf senescence
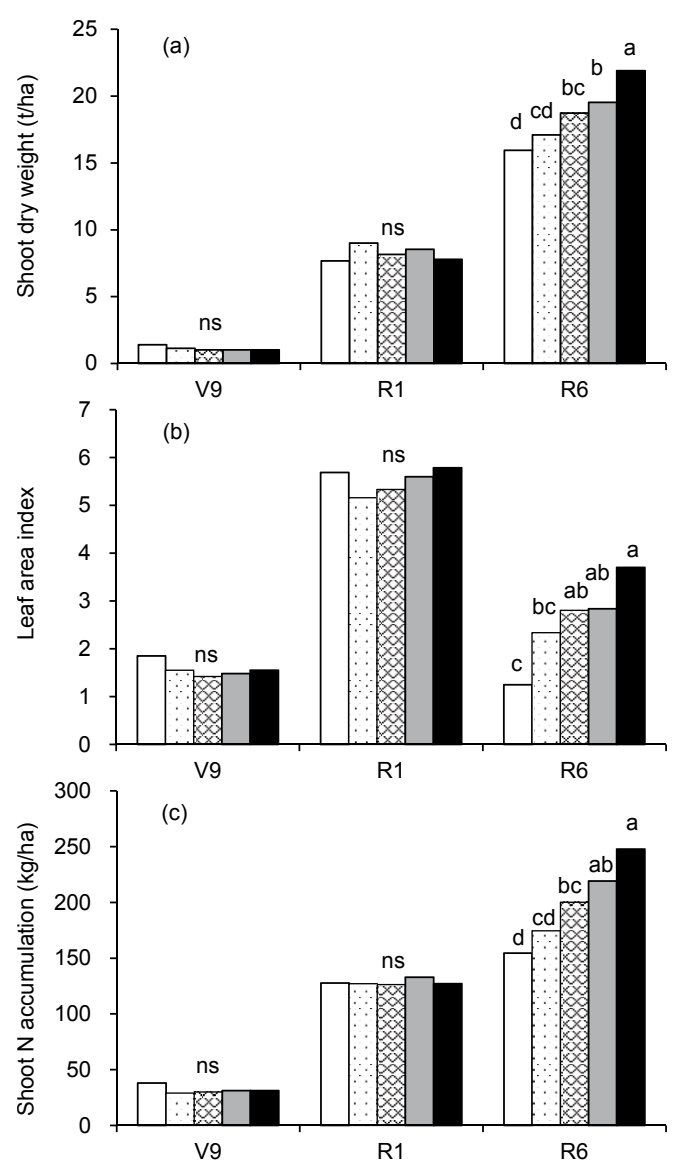

Fig. 1 (a) Shoot dry weight, (b) leaf area index, and (c) shoot nitrogen accumulation at 9 collars stage (V9), silking stage (R1), and physiological maturity (R6) under yield levels of less than $8.25 \mathrm{t} /$ ha (white bars), 8.25$9.75 \mathrm{t} /$ ha (dotted bars), 9.75-11.25 t/ha (net bars), 11.25-12.75 t/ha (grey bars), and greater than $12.75 \mathrm{t} / \mathrm{ha}$ (black bars) in Wuqiao experimental station of China Agricultural University from 2006-2011. Bars with the same letters are not significantly different within each developmental stage, $p<0.05$.

may benefit the increase of grain yield. However, the potential of yield increment through maintaining leaf area was limited (Fig. 2d), i.e., further LAI increment could not improve yield. Nitrogen accumulation in straw and grain were both important for grain dry weight and showed significant correlation with grain dry weight (Fig. 2e and Fig. 2f).

\section{DISCUSSION}

Summer maize growing system has a long history in North China Plain, in which sowing date, plant density, and fertilizer input were all under a high level. However, grain yield became static since the 

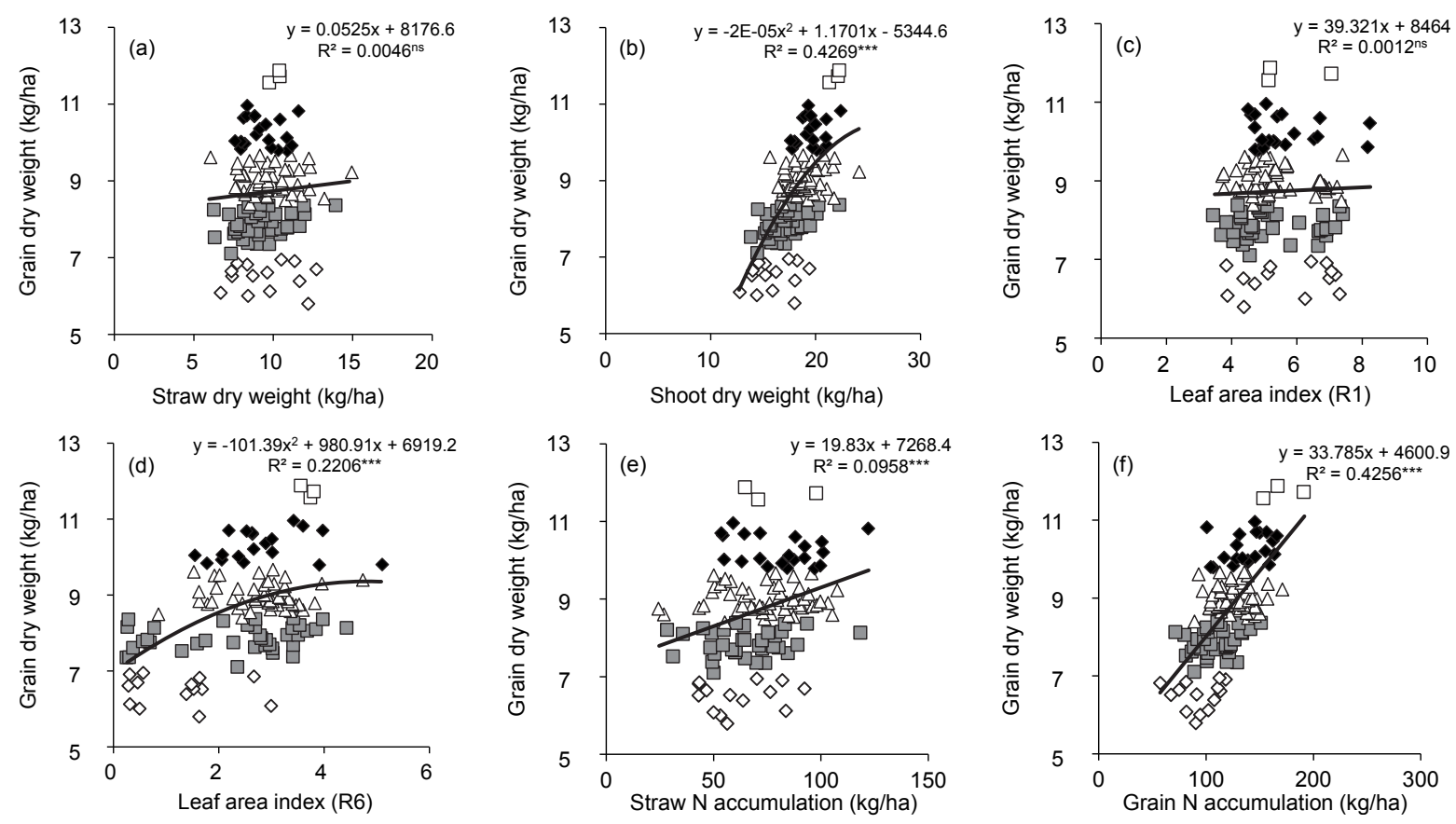

Fig. 2 Correlations between grain dry weight and (a) straw dry weight at physiological maturity, (b) shoot dry weight at physiological maturity, (c) leaf area index at silking stage, (d) leaf area index at physiological maturity, (e) straw N accumulation at physiological maturity, and ( $\mathrm{f}$ ) grain $\mathrm{N}$ accumulation at physiological maturity under yield levels of less than $8.25 \mathrm{t} /$ ha (open diamonds), 8.25-9.75 t/ha (grey squares), 9.75-11.25 t/ha (open triangles), 11.25-12.75 t/ha (filled diamonds), and greater than $12.75 \mathrm{t} / \mathrm{ha}$ (open squares) in Wuqiao experimental station of China Agricultural University from 2006-2011. ns and ${ }^{* * * *}$ represent not significant and significant at $p<0.001$ level, respectively.

2000s. Yield analysis showed that kernel number per ear was the major component positively affected grain yield under plant density of $80000 /$ ha, while 1000-kernel weight maintained at low values across all yield levels (Table 4). Grain yield in maize is a function of the relationship between assimilates supply to the kernel and inherent potential of the kernel to accommodate assimilates ${ }^{14}$. Factors related to kernel number and filling are therefore analysed in the following sections.

\section{Source limitation occurred while hardly to be improved}

Dry matter production around silking is important for kernel formation and filling ${ }^{15}$, and thus determines the yield level. In our experiment however shoot dry weight and leaf area index at silking at all yield levels were at similar ranges (Fig. 1a). As there were larger kernel numbers for high yield (Table 5), it is obvious that assimilated supply (source) to each kernel was insufficient under high yield. Kernel filling was therefore poor and thus kernel weight was less under high yield (Table 4).

Many field management methods had been ap- plied to improve source size in order to increase kernel number and weight, such as increasing plant density, nitrogen, and water input ${ }^{8,16}$. Nevertheless, these measures usually increase lodging risk. We analysed the potential of grain yield increment through increasing total shoot dry weight and leaf area index (Fig. 2). Grain dry weight achieved the highest value of $11.8 \mathrm{t} /$ ha with shoot dry weight of $29.2 \mathrm{t} / \mathrm{ha}$ and low harvest index of 0.40 (Fig. 2b). Additionally, the leaf area index and grain dry weight curve show that an increase of leaf area index will not contribute to grain yield increments under the current field management and variety conditions (Fig. 2d). One possibility to improve source strength might be using new varieties with higher lodging resistance and/or leaf photosynthesis capacity, so that the assimilates supply could be enhanced for kernel differentiation and filling afterwards.

\section{Enhancement of sink strength benefit to grain yield increment}

It has been reported that the increase of straw production contributed more than the increase of 
harvest index to grain production in US Corn Belt ${ }^{17}$. While our data demonstrated that further increase of straw dry weight had no effect on grain yield but caused reduction of harvest index (Fig. 2a). Thus improvement of harvest index through enhancing sink strength might be more helpful to increase grain yield with current Chinese variety (Fig. 2b).

Harvest index could be improved by improving the kernel number per unit of land area, i.e., increasing of plant density and/or kernel number per ear. As the relationship between yield level and plant density was weak under the current high density level (Table 4), improving kernel numbers per ear became a more important issue. The processes determining kernel number per ear were highly sensitive to low level of intercepted radiation or $\mathrm{N}$ supply ${ }^{18}$. In our experiment, straw dry weight, leaf area index and $\mathrm{N}$ accumulation at all yield levels were similar before silking, while differences among yield levels occurred after silking (Fig. 1), i.e., high post-silking dry weight and $\mathrm{N}$ accumulation as well as greater LAI at high yield level. These data implied stronger photosynthesis and $\mathrm{N}$ acquisition capacity of high yield level plants during silking to physiological maturity. When comparing datasets over $\mathrm{N}$ application rates and plant densities, it was clear that a yield greater than $11.25 \mathrm{t} / \mathrm{ha}$ occurred under optimal $\mathrm{N}$ rate $(120-180 \mathrm{~kg} / \mathrm{ha})$ and optimal plant density (8.25 plants $/ \mathrm{m}^{2}$ ). However, there were more plots who received similar growing condition, while obtained low yield. These suggests that factors other than density and $\mathrm{N}$ rate were regulating leaf growth, dry matter accumulation and thus kernel formation after silking.

Moreover, there were still a great potential to improve kernel weight. Thousand-kernel weight of ZD958 was usually around $330 \mathrm{~g}^{19}$, while it was averagely less than $300 \mathrm{~g}$ for all yield level under our experimental conditions (Table 4). The low kernel weight, especially under high yield level, implied problem in kernel filling stage. Kernel weight depends on the potential kernel size established early in kernel filling, and the plant capacity to provide assimilates needed to fulfil this potential during filling ${ }^{20}$. The early stage of kernel filling was a lag phase, which was a period of rapid water accumulation and endosperm expansion and then sink size was determined ${ }^{21}$. Thus root water acquisition and transpiration of leaves shall contribute substantially to sink size at this stage. However, leaf area at silking showed no difference among yield levels (Fig. 1), suggesting a general poor endosperm expansion of summer maize. After lag phase, dry matter under high yield accumulated significantly faster than low yield, which was due to slow leaf senescence under high yield (Fig. 1) and finally led to greater grain yield. Nevertheless, kernel weight could be further improved by enhancing leaf function after silking and especially root function needs also be concerned during this period.

\section{Meteorological and soil condition might limit yield potential}

Typically, maize variety ZD958 could achieve a kernel number per ear of $500-550^{19}$, while it was insufficient in our experimental area, even under high yield level (Table 4). Our experimental area held a typical semi-humid continental monsoon climate, which received plenty of precipitation but less solar radiation in July and August (Table 1). During this critical period for kernel formation fertilization, lack of sunshine negatively affected the yield forma$\operatorname{tion}^{22}$. Moreover, temperature before silking was strongly related to maize yield ${ }^{22}$, thus low temperature at vegetative stage in this area (data not shown) would be another reason of small source size and less kernel differentiation. The low kernel number in high yield limited sink strength and could not drive more assimilates to fill the kernels. Breeding of varieties that matched this climate condition is necessary to further improve the yield.

Moreover, root development might be limited due to poor soil conditions, i.e., high soil bulk density and low nutrient availability (Table 2). Active root $\mathrm{N}$ uptake during grain filling increases canopy photosynthesis duration and final grain yield ${ }^{23}$. However, leaf senescence occurred in our experiments, which should relate to insufficient nutrient supply from the root. Under this situation, the root could not receive sufficient carbohydrates for structure maintenance within this system, which might lead to root senescence. Methods to enhance leaf and root function during this period should therefore be developed to obtain the target yield $\left(>12.75 \mathrm{t} / \mathrm{ha}\right.$ ). Methods such as subsoiling ${ }^{24}$, $\mathrm{N}$ top-dressing after silking, and organic manure application shall be applied in this area to maintain and even improve root function.

\section{Conclusions}

Grain yield of summer maize in this area was limited by insufficient kernel number per ear and low kernel weight, which were due to: (1) source limitation before silking, which was hardly ameliorated simply through improving field managements with current variety, (2) leaf and root senescence from 
silking to physiological maturity, causing lower sink strength, which limited the assimilate production and translocation to grain and root, additionally, (3) low temperature and low sunshine hours as well as high soil bulk density might be factors limiting kernel development and root expansion, and thus yield formation.

Acknowledgements: This work was supported by the Key Sci-tech Project of the "12th 5-year-plan" of China (2011BAD16B15) and State Key Basic R\&D Programme of China (No. 2009CB118602).

\section{REFERENCES}

1. Binder J, Graeff S, Link J, Claupein W, Liu M, Dai M, Wang P (2008) Model-based approach to quantify production potentials of summer maize and spring maize in the North China Plain. Agron J 100, 862-73.

2. Ju X, Liu X, Pan J, Zhang F (2007) Fate of ${ }^{15} \mathrm{~N}$-labeled urea under a winter wheat-summer maize rotation on the North China Plain. Pedosphere 17, 52-61.

3. Sun H, Pei D, Liu C, Zhang X, Chen S (2007) Effects of harvest and sowing time on the performance of the rotation of winter wheat-summer maize in the North China Plain. Ind Crop Prod 25, 239-47.

4. Wang J, Wang E, Yang X, Zhang F, Yin H (2012) Increased yield potential of wheat-maize cropping system in the North China Plain by climate change adaptation. Climatic Change 113, 825-40.

5. Chen C, Wang E, Yu Q (2010) Modeling wheat and maize productivity as affected by climate variation and irrigation supply in North China Plain. Agron $J$ 102, 1037-49.

6. Dai M, Tao H, Liao S, Wang L, Wang P (2008) Estimation and analysis of maize potential productivity based on CERES-MAIZE model in the North China Plain. Trans Chin Soc Agr Eng 24, 30-6, [in Chinese].

7. Zuo H, Liu Y, Yu P, Zhang Y, Wang Z (2012) Dry matter accumulation and water utilization characteristics of two high-yield winter wheat cultivars under limited irrigation and nitrogen supply. $J$ Triticeae Crop 32, 689-95, [in Chinese].

8. Xia L, Tao H, Wang P, Xu X, Lü L, Wang R (2011) Effects of nitrogen application period on nitrogen accumulation, translocation and nitrogen use efficiency of summer maize. J Maize Sci 19, 112-6, [in Chinese].

9. Xu L, Huang S, Tao H, Wang Y, Qi L, Wang P (2012) Effects of different nitrogen regimes on canopy structure and partial physiological and agronomic traits in summer maize. Acta Agron Sin 38, 301-6, [in Chinese].

10. Lü L, Tao H, Wang P, Liu M, Zhao M, Wang R (2008) Carbon and nitrogen metabolism and nitrogen use efficiency in summer maize under different planting densities. Acta Agron Sin 34, 718-23, [in Chinese].
11. Huang S, Xu L, Tao H, Dong Z, Wang P (2012) Effect of plant type regulation on canopy structure and physiology of summer maize. J China Agr Univ 17, 40-5, [in Chinese].

12. Wang Q, Wang P, Zhai Z, Wang Z, Fu J (2004) Dynamics of soil inorganic nitrogen and its net mineralized amount affected by nitrogen application timing during maize season. Agr Res Arid Area 22, 11-6, [in Chinese].

13. Wang C, Tao H, Wang P, Dai M (2010) Grain yield, dry matter productivity and nitrogen use efficiency of summer maize under reduced $\mathrm{N}$ supply at earlier stage. J Maize Sci 18, 99-104, [in Chinese].

14. Jones RJ, Simmons SR (1983) Effect of altered source-sink ratio on growth of maize kernels. Crop Sci 23, 129-34.

15. Otegui ME, Nicolini MG, Ruiz RA, Dodds PA (1995) Sowing date effects on grain yield components for different maize genotypes. Agron J 87, 29-33.

16. Zhao S, He P (2012) Evaluation of in-season nitrogen management for summer maize in the North China Plain. Better Crop Plant Food 96, 8-10.

17. Lorenz AJ, Gustafson TJ, Coors JG, de Leon N (2010) Breeding maize for a bioeconomy: a literature survey examining harvest index and stover yield and their relationship to grain yield. Crop Sci 50, 1-12.

18. Rajcan I, Tollenaar M (1999) Source : sink ratio and leaf senescence in maize: I. Dry matter accumulation and partitioning during grain filling. Field Crop Res 60, 245-53.

19. Zhang $X$ (2011) Introduction on maize variety Zhengdan 958, www.farmers.org.cn/Article/ ShowArticle.asp?ArticleID=109867, [in Chinese].

20. Borrás L, Gambín BL (2010) Trait dissection of maize kernel weight: Towards integrating hierarchical scales using a plant growth approach. Field Crop Res 118, 1-12.

21. Borrás L, Westgate ME (2006) Predicting maize kernel sink capacity early in development. Field Crop Res 95, 223-33.

22. Ming B, Zhu J, Tao H, Xu L, Guo B, Wang P (2013) Effects of meteorological factors at different growth stages on yield traits of maize (Zea mays L.) in Heilonggang Basin. Acta Agron Sin 39, 919-27, [in Chinese].

23. Ciampitti IA, Vyn TJ (2011) A comprehensive study of plant density consequences on nitrogen uptake dynamics of maize plants from vegetative to reproductive stages. Field Crop Res 121, 2-18.

24. Jin P, Ren W, Tao H, Wang P (2014) Effects of subsoiling on dry matter production, photosynthetic performance and root development of summer maize. J Maize Sci 22, 114-20, [in Chinese]. 